\title{
Pengaruh Ketinggian Perangkap Feromon terhadap Penggerek Buah Kakao Conopomorpha cramerella Snell. (Lepidoptera: Gracillaridae)
}

\author{
Betty Sahetapy*, Ester D. Masauna, Darwanti, dan Nureny Goo \\ Program Studi Agroteknologi, Fakultas Pertanian, Universitas Pattimura, Ambon \\ Jl. Ir. M. Putuhena Poka, Ambon 97233 \\ *Alamat korespondensi: bettysahetapy@gmail.com
}

\begin{tabular}{lrc}
\hline \multicolumn{2}{c}{ INFO ARTIKEL } & ABSTRACT/ABSTRAK \\
\hline Diterima: & $17-08-2021$ & Effect of Pheromone Trap Height on Cocoa Pod Borer Conopomorpha \\
Direvisi: & $18-11-2021$ & cramerella Snell. (Lepidoptera: Gracillaridae) \\
Dipublikasi:23-01-2022 &
\end{tabular}

Keywords:

C. cramerella, Cocoa, Height, Pheromone, Trap

Kata Kunci:

C. cramerella, Kakao, Feromon, Ketinggian, Perangkap
Cocoa pod borer/CPB (Conopomorpha cramerella Snell.) is one of the pests that at a severe level attack result in cocoa yield loss up to $90 \%$. This study aimed to test environmentally friendly $\mathrm{CPB}$ control technology, namely the use of sex pheromone traps in the aspect of an effective trap height position. The study was conducted in Banda Lama Village, Amahai Sub-district, Central Maluku District from January to March 2019. This study tested the height of the pheromone trap at three different height positions of the pheromone trap, namely $1 \mathrm{~m}, 2 \mathrm{~m}$ and $3 \mathrm{~m}$. The observed data was the number of $C$. cramerella imago caught for each treatment. The results showed that the pheromone trap with a height of $1 \mathrm{~m}$ was the most effective trap position in trapping $\mathrm{CPB}$ with a total catch of 85 imago and the average of trapped imago population was 10.63 imago/month.

Hama penggerek buah kakao/PBK (Conopomorpha cramerella Snell.) merupakan salah satu hama yang pada tingkat serangan berat dapat mengakibatkan kehilangan hasil kakao mencapai 90\%. Penelitian ini bertujuan untuk menguji teknologi pengendalian hama PBK yang ramah lingkungan yaitu penggunaan perangkap feromon seks pada aspek posisi ketinggian perangkap yang efektif. Penelitian dilaksanakan di desa Banda Lama, Kecamatan Amahai, Kabupaten Maluku Tengah yang berlangsung dari bulan Januari sampai Maret 2019. Penelitian ini menguji ketinggian perangkap feromon pada tiga posisi ketinggian perangkap feromon yang berbeda yaitu ketinggian $1 \mathrm{~m}, 2 \mathrm{~m}$ dan $3 \mathrm{~m}$. Data yang diambil adalah jumlah tangkapan imago $C$. cramerella tiap perlakuan. Hasil penelitian menunjukkan bahwa perangkap feromon dengan ketinggian $1 \mathrm{~m}$ yang paling efektif memerangkap hama PBK dengan jumlah tangkapan 85 ekor dan rerata populasi imago terperangkap adalah 10,63 ekor/bulan.

\section{PENDAHULUAN}

Kakao (Theobroma cacao L.) merupakan salah satu tanaman perkebunan penting di Indonesia karena selain sebagai sumber penghasilan bagi petani maupun masyarakat lainnya juga merupakan penghasil devisa negara. Indonesia mempunyai perkebunan kakao paling luas di dunia yaitu sekitar
1.691.334 ha yang terdiri dari $90 \%$ perkebunan rakyat dan sisanya perkebunan swasta dan negara, dengan produksi mencapai 688.345 ton/tahun, sedangkan perkebunan kakao di Maluku memiliki luas area yaitu 28.131 ha dan produksi kakao sebesar 9.942 ton. Luas perkebunan rakyat di Maluku Tengah yaitu 9.608 ha dengan produksi mencapai 3.191 ton (Direktorat Jendral Perkebunan, 2019). 
Salah satu OPT utama yang menjadi ancaman serius bagi keberlanjutan budidaya kakao adalah penggerek buah kakao/PBK (Conopomorpha cramerella Snellen). Hama ini menjadi prioritas utama untuk dikendalikan mengingat kecenderungan intensitas dan luas serangannya semakin meningkat (Sulistyowati, 2003). Pengelolaan dan penanganan yang objektif, diharapkan dapat meningkatkan hasil produksi dari buah kakao akibat serangan hama PBK. Rata-rata persentase serangan PBK di sentra produksi kakao nasional mencapai lebih dari 90\% dengan potensi kehilangan hasil 30\% - 80\% (Sulistyowati, 2007; Sulistyowati dkk., 2007). Kerusakan buah kakao disebabkan oleh larva PBK dengan cara membuat liang gerekan di bawah kulit buah dan di antara biji serta memakan daging buah pada buah yang relatif muda.

Hal itu menyebabkan biji melekat pada kulit buah dan melekat satu sama lain, namun tidak menimbulkan kerusakan berarti pada biji tapi dapat menurunkan mutu biji pada buah matang (Hayata, 2017). Upaya untuk mengendalikan hama PBK sering dilakukan oleh petani yaitu dengan cara menggunakan insektisida. Namun demikian, pada kenyataannya penggunaan insektisida tanpa didasari pengetahuan biologi hama dan teknik aplikasi yang benar mengakibatkan tidak tercapainya tujuan pengendalian. Lebih jauh lagi hal tersebut dapat berpotensi menimbulkan berbagai dampak negatif terhadap manusia dan kelestarian lingkungan hidup, diantaranya dapat mengganggu kesehatan petani dan konsumen, pencemaran lingkungan, membunuh flora dan fauna non target, menimbulkan resistensi maupun resurgensi hama.

Teknologi ramah lingkungan lainnya yang pernah digunakan adalah pengendalian hama dengan cara kultur teknis berupa pemangkasan tanaman kakao maupun tanaman pelindung, pemupukan, sanitasi, panen sering. Semakin luasnya penyebaran hama $C$. cramerella dan besarnya kerugian yang ditimbulkan, maka perlu dicari metode penanggulangan hama $C$. cramerella yang efektif dan efisien serta ramah lingkungan. Salah satu pengendalian hama PBK yaitu pengendalian dengan feromon seks.

Teknologi pengendalian PBK dengan feromon seks merupakan pengendalian dengan pendekatan ramah lingkungan dan mudah dilakukan petani, sehingga penggunaan insektisida yang berlebihan ditingkat petani dapat dihindari. Pengendalian $C$. cramerella melalui perangkap (trapping) imago $C$. cramerella menggunakan feromon seks saat ini sudah mulai dikembangkan. Senyawa ini merupakan senyawa sintetik dari ekstrak senyawa feromon seks yang dikeluarkan oleh imago betina PBK yaitu hexadecatrienly acetate $60 \%$ + hexadecatrienol $40 \%$ (Witjaksono, 2007).

Intensitas serangan PBK pada perlakuan dengan menggunakan perangkap feromon seks mengakibatkan penuruan intensitas serangan yang lebih baik dibandingkan dengan perlakuan menggunakan pestisida. Pada pengamatan pertama (30 hari) setelah pemasangan perangkap intensitas serangan sebesar 2,23\% dibandingkan dengan perlakuan pestisida sebesar $4,49 \%$, bahkan intensitas serangan dapat mencapai $0,00 \%$ dibandingkan perlakuan pestisida dengan intensitas serangan 1,43\% pada pengamatan berikutnya (Muliku dkk., 2017). Navies (2004) menyebutkan feromon seks serangga $C$. cramerella Snell. telah diuji sebagai salah satu kaidah untuk mengawali pengendalian dan mengurangi penggunaan pestisida dimana dengan banyaknya serangga jantan yang tertangkap maka perkawinan dan peletakan telur oleh serangga betina tidak terjadi sehingga serangan pada buah dapat menurun. Dari hasil pengamatan pemasangan perangkap di Papua Nugini feromon dapat menangkap ratarata 5-6 ekor imago jantan penggerek buah kakao per hari yang melekat pada perangkap berperekat (Sulistyowati, 2007).

Di Maluku penggunaan perangkap feromon sudah dilakukan oleh Luhukay dkk. (2017) dan Sahetapy dkk. (2018) terhadap hama Oryctes rhinoceros L. pada tanaman kelapa, dari hasil pemasangan perangkap feromon dapat memerangkap O. rhinoceros 6 ekor (perangkap lampu) dan 19 ekor (perangkap feromon + lampu). Sementara itu, penggunaan perangkap feromon ( $C P B$-lure) terhadap hama $C$. cramerella sudah dilakukan oleh BBPPTP Maluku di Kecamatan Amahai tetapi sampai saat ini belum mendapatkan data yang lengkap. Oleh karena itu perlu dilakukan penelitian untuk melihat efektifitas perangkap feromon terhadap penggerek buah kakao C. cramerella di Kecamatan Amahai.

\section{BAHAN DAN METODE}

Penelitian dilaksanakan di lahan kakao, Kecamatan Amahai (Desa Banda lama), Kabupaten Maluku Tengah dari bulan Januari sampai Maret 2019. Pada penelitian ini diuji ketinggian perangkap yang berbeda yaitu: PF1 = perangkap feromon dengan ketinggian $1 \mathrm{~m}$ di atas permukaan tana, $\mathrm{PF} 2=$ perangkap feromon dengan ketinggian $2 \mathrm{~m}$ di atas 
permukaan tanah dan PF3 = perangkap feromon dengan ketinggian $3 \mathrm{~m}$ di atas permukaan tanah. Perlakuan diulang sebanyak 5 kali sehingga jumlah seluruh satuan percobaan adalah 15 satuan percobaan.

Pelaksanaan penelitian meliputi beberapa tahapan yaitu:

1. Peninjauan lokasi

Survey lokasi penelitian bertujuan untuk mengetahuai keadaan lokasi yang akan dijadikan tempat pelaksanaan penelitian di lahan pertanaman kakao milik beberapa petani.

2. Perangkap feromon

Perangkap dengan feromon terdiri dari tiga bagian yaitu vial feromon berbentuk tabung vial, tabung berbahan plastik PVC berwarna putih, panjang tabung $25 \mathrm{~cm}$, diameter tabung $8 \mathrm{~cm}$ yang digantung pada bagian dalam trap delta. Sticky liner yaitu kertas berlapis plastik dengan lem diletakkan pada bagian dasar trap delta. Trap delta yaitu Perangkap kuning.

3. Pemasangan perangkap

Setiap feromon dipasang menggunakan perangkap delta yang telah diberi lem dan digantung pada ranting tanaman kakao dengan ketinggian $1 \mathrm{~m}, 2 \mathrm{~m}$ dan $3 \mathrm{~m}$ di atas permukaan tanah. Jarak antara pohon sampel yaitu 33 meter.

4. Waktu pengamatan

a. Populasi C. cramerella diamati setiap 7 hari sekali, selama 8 minggu dan diamati pada pukul 07.00-12.00 WIT. Populasi hama $C$. cramerella diperoleh dengan cara mengambil imago yang tertangkap.

b. Suhu selama penelitian

Pengamatan suhu dilakukan pada pukul 06.00, 12.00 dan 18.00 dengan menggunakan thermohygrometer di lapangan.

\section{Variabel Pengamatan}

Variabel yang diamati dalam penelitian ini adalah banyaknya serangga jantan dewasa hama $C$. cramerella yang terperangkap pada perlakuan yang diuji.

\section{Analisis data}

Data yang diperoleh ditabulasi dan dihitung rata-rata populasi hama PBK (C. cramerella) pada tiap perlakuan dengan menggunakan analisis kuantitatif sederhana:
Keterangan:

$$
\mu=\frac{\sum x_{i}}{n}
$$

M : Rata-rata populasi hama PBK tiap perlakuan (ekor)

$X_{i} \quad$ : Jumlah hama PBK yang terperangkap

$\mathrm{N}$ : Banyaknya ulangan

\section{HASIL DAN PEMBAHASAN}

\section{Jumlah Tangkapan Imago $C$. cramerella pada Tiap Bulan}

Hasil penelitian menunjukkan bahwa jumlah tangkapan C. cramerella pada perangkap feromon dengan ketinggian $1 \mathrm{~m}$ memerangkap hama $C$. cramerella tertinggi yaitu 85 ekor imago terperangkap adalah 10,63 ekor/bulan (Gambar 1). Pada ketinggian perangkap feromon $2 \mathrm{~m}$ diperoleh 42 ekor dengan rerata populasi 5,25 ekor/bulan serta pada ketinggian $3 \mathrm{~m}$ memerangkap 32 ekor dengan rerata populasi 4 ekor/bulan. Hal ini disebabkan karena pada ketinggian $1 \mathrm{~m}$ ketersediaan pakan untuk larva dan imago dimana buah dan bunga umumnya terletak pada pangkal pohon kakao hingga ketinggian $2 \mathrm{~m}$ untuk menyelesaikan siklus hidupnya.

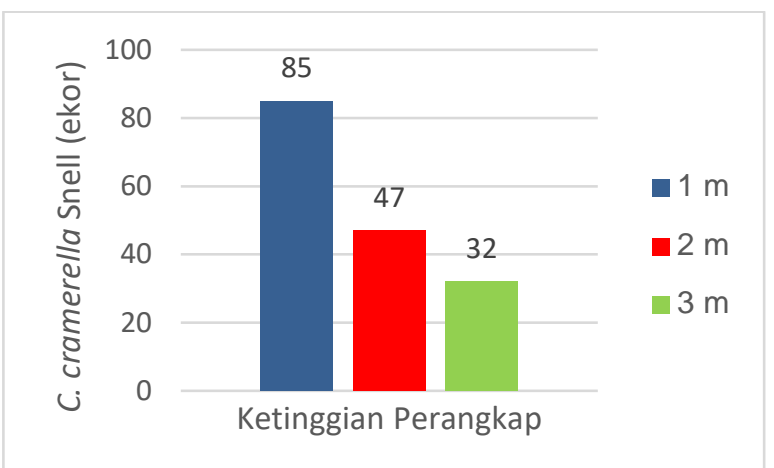

Gambar 1. Jumlah tangkapan imago C. cramerella tiap perlakuan

Varietas kakao yang dibudidayakan oleh petani adalah kakao hibrida, kakao hibrida merupakan kakao hasil persilangan antara Criolo dan Foreteri. Tetua dari kakao hibrida ini memiliki buah yang beralur dalam sehingga pada varietas hibrida yang dibudidayakan yang memiliki buah beralur ini sangat cocok untuk hama PBK meletakkan telur. Hama PBK bertelur dan meletakkan telurnya pada alur kulit buah kakao yang berlekuk atau memiliki alur buah yang agak dalam sehingga lebih mudah meletakkan telur (Ridwan \& Nurmiaty, 2017; Syatrawati \& Asmawati, 2015). Semakin banyak telur yang dapat diletakkan oleh imago PBK diduga dapat 
meningkatkan serangan PBK karena larva lebih mudah mengifeksi masuk ke dalam buah (Syatrawati \& Asmawati, 2015). Kulit buah yang memiliki alur dalam lebih disukai PBK karena mempermudah peletakan telur pada alur buah. Telur yang telah diletakkan pada alur buah yang dalam dapat menahan telur dari terpaan air hujan atau angin, sedangkan telur pada buah yang beralur dangkal lebih mudah terlepas dari kulit buah apabila terkena air hujan atau angin. Demikian juga kondisi lingkungan yang lembab dan gelap merupakan tempat yang ideal untuk hama PBK, kurangnya sinar matahari yang masuk akan membuat hama PBK berkembang dengan baik. Kebun yang tidak terawat, penuh sampah sisa panen, gulma dan ranting atau daundaun kering (serasah) merupakan tempat hidup hama PBK pada fase pupa kemudian setelah 5-7 hari menjadi serangga dewasa (imago).

Hama PBK yang baru menjadi imago memerlukan waktu 2-3 hari untuk memasuki periode matang seksual sehingga saat imago mencari makanan untuk kelangsungan hidupnya, imago juga mencari pasangan untuk berkopulasi (Blum, 1984). Bau feromon dari imago betina membuat imago jantan berusaha mencari sumber feromon. Perangkap feromon ketinggian $1 \mathrm{~m}$ merupakan sasaran utama karena lebih dekat dengan sumber pakan dan kemampuan terbangnya yang rendah (Gambar 2). Molekul-molekul feromon yang dilepaskan ke udara harus dapat mencapai antena imago jantan. Jika feromon diabsorbsi pada antena, bahan ini akan berdifusi ke dalam pori, dimana reseptor dendrit akan cocok dengan struktur molekul feromon dan akan membangkitkan rasngsangan pada neuron. Rangsangan akan dikirim dengan aksi keputusan untuk merespon atau tidak.

Feromon seks bekerja sebagai penghubung antara individu jantan dan individu betina sehingga keduanya dapat menjalankan kopulasi (Blum, 1984). Imago jantan yang tertarik kemudian menuju keperangkap feromon dan terperangkap terjadi pemutusan perkawinan (mating disruption). Daya terbang dari hama $C$. cramerella rendah dan memerlukan bantuan angin untuk mencapai ketinggian yang lebih dari $1 \mathrm{~m}$ sehingga hama $C$. cramerella mencapai sumber feromon yang terdekat. Faktor- faktor di atas menyebabkan perangkap feromon dengan ketinggian $2 \mathrm{~m}$ dan $3 \mathrm{~m}$ memerangkap hama $C$. cramerella lebih sedikit. Blum (1984) juga menyatakan bahwa molekul-molekul feromon sangat spesifik, artinya hanya mendapat tanggapan dari serangga dengan jenis yang sama.
Selain faktor tersebut pada siang hari imago bersembunyi di tempat yang terlindung dari sinar matahari yaitu pada bagian bawah cabang horizontal dengan diameter $0-5 \mathrm{~cm}$ dan $>20 \mathrm{~cm}$ (Sudarsianto,1995).

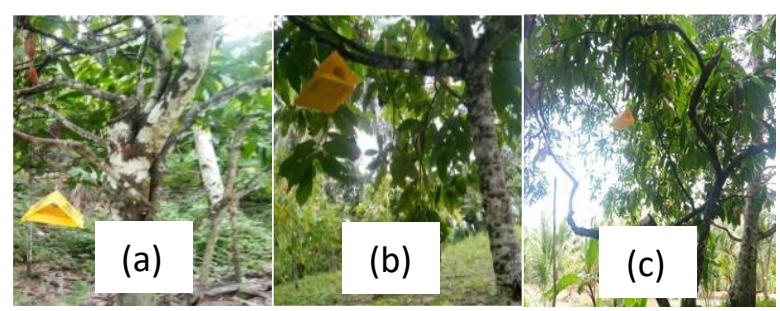

Gambar 2. Pemasangan perangkap feromon pada tanaman kakao dengan ketinggian: (a) 1 $\mathrm{m}$, (b) $2 \mathrm{~m}$, (c) $3 \mathrm{~m}$

\section{Jumlah Tangkapan Imago C. Cramerella Snell. Tiap Minggu Pengamatan}

Hasil jumlah tangkapan $C$. cramerella tiap minggu dapat dilihat pada Gambar 3. Jumlah imago hama $C$. cramerella yang terperangkap mengalami fluktuasi dan semakin lama semakin berkurang. Hal ini disebabkan karena molekul-molekul feromon yang dilepaskan ke udara semakin berkurang. Penurunan jumlah hama $C$. cramerella yang terperangkap terjadi pada perlakuan perangkap feromon pada ketinggian $1 \mathrm{~m}, 2 \mathrm{~m}$ dan $3 \mathrm{~m}$. Hal ini disebabkan oleh penggunaan feromon yang bersifat volatil akan berkurang kuantitasnya akibat penguapan, sehingga bau (senyawa kimia) dari feromon perlahan-lahan akan hilang dan tidak berpengaruh lagi pada hama PBK. Sulistyowati (2007) menyatakan bahwa di Papua Nugini feromon dapat bertahan 2 bulan dan dapat menangkap rata-rata 5-6 ekor C. cramerella per hari.

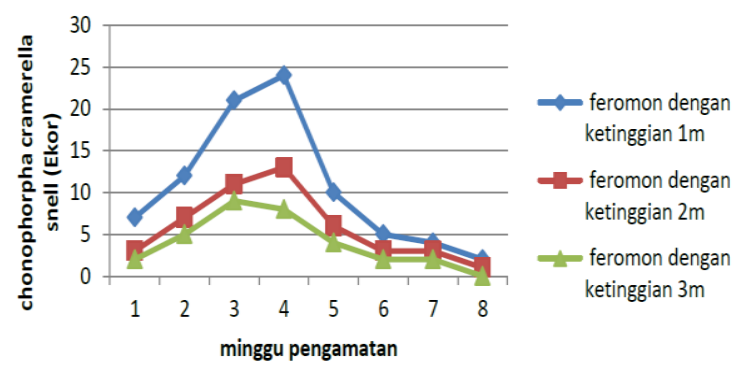

Gambar 3. Jumlah tangkapan imago C. cramerella tiap minggu pengamatan

Fero-PBK mengandung feromon seks yang digunakan untuk menangkap hama $C$. cramerella jantan secara massal. Tertangkapnya serangga jantan maka perkawinan tidak terjadi sehingga serangan 
pada buah dapat menurun. Menurut Bakhri dkk. (2010) penggunaan fero-PBK sangat efektif dalam memerangkap serangga jantan $C$. cramerella dan menurunkan tingkat serangan $C$. cramerella. Sementara itu, Sulistyowati (2014) menyebutkan bahwa penggunaan feromon seks untuk monitoring atau penangkapan massal $C$. cramerella sebagai salah satu faktor dalam PHT yang cukup menjanjikan karena sifatnya spesifik sasaran, ramah lingkungan, efektif, dan ekonomis.

Faktor eksternal dapat memengaruhi pertumbuhan kakao dan kepadatan populasi $C$. cramerella seperti ketinggian tempat, curah hujan, suhu, dan kelembapan di setiap lokasi (Syarkawi dkk., 2015). Populasi C. cramerell umumnya akan lebih sedikit di musim hujan dan akan lebih tinggi di musim kemarau. Ini karena tingginya curah hujan memengaruhi mobilitas ngengat (Wiryadiputra, 1996). Di musim kemarau dengan meningkatnya jumlah buah kakao, populasi C. cramerell akan meningkat dengan cepat juga (Wardojo, 1980). Rata-rata curah hujan pada pada saat penelitian yaitu $142 \mathrm{~mm}$, kondisi ini sesuai bagi ngegat untuk bertelur (Prawoto dkk., 2003; Sulistyowati, 2003). Kondisi cuaca yang sesuai bagi ngengat untuk bertelur adalah pada curah hujan $100-200 \mathrm{~mm}$ per bulan (Lim, 1986). Seekor ngengat betina dapat menghasilkan telur 100-200 butir (Prawoto dkk., 2003; Sulistyowati, 2003).

Nietschke et al. (2007) menyatakan bahwa suhu menjadi faktor yang relevan yang memengaruhi aktivitas hama, sedangkan suhu yang tidak mendukung akan memperpendek umur serangga (Jumar, 2010). Disebutkan bahwa wilayah yang vegetasinya lebat dapat menyebabkan suhu udara rendah dan kelembaban nisbi (RH) tinggi, sebaliknya pada keadaan sama tapi vegetasinya renggang maka RH lebih rendah (Syarkawi dkk., 2015). Syarkawi dkk. (2015) juga menjelaskan bahwa fluktuasi kelembaban berperan sangat besar dalam mengatur aktivitas organisme dan sering menjadi faktor pembatas terhadap dinamika populasi dan penyebaran serangga. Kelembaban udara sangat berperan dalam mendukung aktivitas C. cramerell untuk meletakkan telur pada buah kakao. Pada umumnya serangga sangat rentan kekeringan, khususnya dalam melakukan oviposisi dan pada stadia larva yang keluar dari buah untuk pupasi dan kemunculan imago juga dipengaruhi oleh kelembaban tanah yang optimal bagi kehidupan pupa adalah antara $80-90 \%$ (Sodiq, 1993). Dalam penelitian ini faktor suhu dan kelembaban tidak berpengaruh terhadap penyebaran serangga. Hasil pengamatan rata-rata suhu dan kelembapan selama penelitian adalah ratarata suhu $32,125^{\circ} \mathrm{C}$ dan rata-rata kelembapan $62,75 \%$. Dapat dikatakan bahwa suhu dan kelembaban mendukung terhadap aktivitas serangga.

\section{SIMPULAN}

Perangkap feromon dengan ketinggian $1 \mathrm{~m}$ yang paling efektif memerangkap hama PBK ( $C$. cramerella) dengan jumlah tangkapan 85 ekor dan rerata populasi imago terperangkap adalah 10,63 ekor/bulan.

\section{DAFTAR PUSTAKA}

Bakhri, SA Ardjanhar, dan M Abid. 2010. Pendampingan Gernas Kakao melalui Media Cetak dan Demplot di Sulawesi Tengah. Laporan Hasil PengKajian BPTP Sulteng Tahun 2010. Biromaru, Sulawesi Tengah.

Blum, MS. 1984. Exocrine yystem. In Pp. 535-578. Fundamentals of Insect Physiology (MS Blum, Ed). John wiley \& Sons. New York.

Direktorat Jendral Perkebunan. 2019. Statistik Perkebunan Indonesia. Kementrian Pertanian. Jakarta.

Hayata. 2017. Tingkat serangan hama penggerek buah kakao (Conopomorpha cramerella Snell.) (Lepidoptera: Gracillaridae) di Desa Betung Kecamatan Kumpeh Ilir Kabupaten Muaro Jambi. Jurnal Media Pertanian. 2(2): 92-97.

Jumar. 2010. Entomologi Pertanian. Rineka Cipta. Jakarta.

Lim, GT. 1986. Seasonal fluctuation of cocoa podborer Conophomorpha cramerella Sn. in Taiwan. Sabah Proc. Int Conf. Pl. Prot in the Tropies. Malaysian Plan Prot. Soc. (MAPPS). Kuala Lumpur. 114 p.

Luhukay, R, B Sahetapy, dan A Umasangadji. 2017. Uji efektivitas beberapa jenis perangkap terhadap kumbang tanduk (Oryctes rhinoceros L.) (Coleoptera; Scarabaeidae). Jurnal Budidaya Pertanian. 13: 30 -35.

Muliku, SJ, M Tulung, dan BAN Pinaria. 2017. Pengendalian Conophomorpha cramerella Snellen menggunakan feromon seks di Desa Makarti Jaya Kabupaten Pohuwato Provinsi Gorontalo. Eugenia. 23(2): 58-61. 
Navies, M. 2004. Semiokimia Buah Koko. Lembaga Koko Malaysia. Malaysia.

Nietschke, BS, RD Magarey, DM Borchert, DD Calvin, and E Jones. 2007. A developmental database to support insect phenology models. Crop Protection. 26(9): 1444-1448.

Prawoto, AA, P Rahardjo, S Abdoellah, SS Sukamto, S Winarsih, MB Odang, D Suhendi, S Wiryadiputra, dan Sulistyowati. 2003. Pedoman Teknis Budidaya Tanaman Kakao (Theobroma cacao L.). Puslitkoka Jember, September 2003. $103 \mathrm{hlm}$.

Ridwan, A, dan Nurmiaty. 2017. Preferensi Conopomorpha cramerella pada beberapa karakter morfologi buah kakao. J. AgroPlantae. 6(2): 1-5.

Sahetapy, B, ED Masauna, dan R Luhukay. 2018. Uji efektivitas perangkap feromon terhadap hama Oryctes rhinoceros L. dan intensitas kerusakan pada tanaman kelapa di Desa Latuhalat, Kecamatan Nusaniwe, Pulau Ambon. Jurnal Agrikultura. 29(1): 19-25.

Syatrawati, dan Asmawati. 2015. Tingkat serangan hama penggerek buah kakao (Conopomorpha cramerella Snellen) pada lima klon kakao lokal. J. Agroplantae. 4(1): 25-29.

Sodiq, M. 1993. Aspek Biologi dan Sebaran Populasi Lalat Buah pada Tanaman Mangga dalam Kaitannya dengan Pengembangan Model Pengendalian Hama Terpadu. [Disertasi]. Program Pasca Sarjana Universitas Airlangga. Surabaya.

Sudarsianto. 1995. Studi Perilaku Imago hama Penggerek Buah Kakao (PBK). Puslitkoka. Jember.

Sulistyowati, E. 2003. Pengaruh serangan hama penggerek buah kakao (PBK) terhadap mutu biji kakao. Warta Pusat Penelitian Kopi dan Kakao. 15: 29-36.

Sulistyowati, E. 2007. Hasil identifikasi dan klarifikasi serangan hama penggerek buah kakao di Papua New Guinea. Warta Pusat Penelitian Kopi dan Kakao Indonesia. 22(1): 28-36.

Sulistyowati, E, E Mufrihati, dan S Wardani. 2007. Potensi insektisida berbahan aktif ganda sipermetrin plus klorpirifos dalam mengendalikan penggerek buah kakao, Conopomorpha cramerella Snell. Warta Pusat Penelitian Kopi dan Kakao Indonesia. 23(3): 159-167.

Sulistyowati E. 2014. Keefektifan feromon sex untuk mengendalikan hama penggerek buah kakao Conopomorpha cramerella Snellen. Pelita Perkebunan. 30 (2): 115-122.

Syarkawi, Husni, dan M. Sayuti. 2015. Pengaruh ketinggian tempat terhadap tingkat serangan hama penggerek buah kakao (Conopomorpha Cramerella Snellen) di Kabupaten Pidie. Jurnal Floratek 10 (2): 52-60.

Wardojo, S. 1980. The cocoa pod borer: A mayor hindrance to cocoa development. Indonesia Agricultural Research Development of Journal. 2: 1-4.

Wiryadiputra, S. 1996. Hama penggerek buah kakaokendala utama industri kakao Indonesia dan sarana pengelolaannya. Jurnal Perlindungan Tanaman Indonesia. 2(1): 16-23.

Witjaksono, 2007. Seks Feromon Penggerek Buah Kakao (Conopomorpha cramerella): Sintesis dan Uji lapang. LPPM Universitas Gadjah Mada. Yogyakarta. 